\section{Odunvbun ME Adeyekun AA}

\title{
Ultrasonic assessment of the prevalence of gall stones in sickle cell disease children seen at the University of Benin Teaching Hospital, Benin City, Nigeria
}

DOI:http://dx.doi.org/10.4314/njp.v41i4,16

Accepted: 17th July 2014

Odunvbun ME ( $\square)$

Department of Child Health

Adeyekun AA

Department of Radiology

University of Benin Teaching Hospital

Benin-City, Edo State, Nigeria

Email: magodunvbun@yahoo.com

\begin{abstract}
Background: Gallstone is a common problem in patients with sickle cell disease. Prevalence of this problem among sickle cell disease (SCD) children may vary with age, and geographic location. Studies on gallstone prevalence in SCD children are scanty in the South-South zone of Nigeria.

Aim: To determine by ultrasonography the prevalence of gallstones among steady state sickle cell disease children attending the Paediatric Outpatient Clinic of the University of Benin Teaching Hospital, Benin-City, south south Nigeria.

Methodology: The study was a descriptive cross sectional study. The prevalence of gall stones was studied prospectively on 101 sickle cell disease patients who attended the Paediatric Outpatient clinic of the University of Benin Teaching Hospital by means of ultrasonography. They were aged 1-18 years. All except three patients were Haemoglobin $(\mathrm{Hb}) \mathrm{SS}$ while the remaining three were HbSC. Statistical analysis was done by means, percentages and tests of significance was done using students $\mathrm{t}-$ test.

Results: Five of the 101 children studied had gallstones and one had biliary sludge. The prevalence of gallstone was 5\%. All
\end{abstract}

patients with gallstones were HbSS, none with HbSC had stone although only three were studied. Only one child was symptomatic for the presence of gallstones. One patient had biliary sludge. The male: female ratio was 4:1. Prevalence increased with age; $2.9 \%$ $4.5 \%$ and $9.1 \%$ in patients aged less than 5,6-10 and 11-18 years respectively. Body weight was significantly associated with the presence of gallstones.

Conclusion: Gallstone was found in $5 \%$ of the SCD children aged 118years. This value is low compared to those from Europe and North America. It however confirmed the relative low prevalence in the general population of Nigerians. The clinical significance of gallstones in these SCD children is that it may contribute significantly to the morbidity and mortality seen in these children.

Recommendation: Routine abdominal scan is recommended for sickle cell disease children to detect gallstone whose presence can mimic abdominal crisis. The option of elective cholecystectomy with reduced morbidity compared to emergency cholecystectomy can thus be exploited.

Key words: Sickle cell disease, gallstones, biliary, sludge, BeninCity, ultrasound.

\section{Introduction}

Sickle cell disease (SCD) is the commonest haemoglobinopathy seen in Nigeria with a prevalence of $3 \%$ in the newborn population ${ }^{1}$. The commonest phenotypes are the homozygous SS or Sickle cell anemia, and less common are the compound heterozygote Haemoglobin
$\mathrm{SC}$. The disease is a chronic haemolytic disorder associated with increased bilirubin production and jaundice ${ }^{2}$. Hyper-haemolytic crisis usually following sepsis contributes greatly to increase bilirubin production. Third generation cephalosporins are known to crystallize in the gallbladder ${ }^{2-3}$ and their use in treating infections which is a common problem in SCD is thought to contribute to 
the high prevalence of stones seen in these patients ${ }^{2}$. Vaso-occlusive events, acute sequestration crisis and recurrent febrile episodes from bacterial infections constitute the common acute events associated with the disease. However, chronic events also occur and formation of gallstone as a result of the chronic haemolysis is one of such complication. Gallstone in SCD patients are usually pigment stones composed largely of calcium bilirubinate. It is thought that gallstones create a nidus of infection, predisposing affected patients to higher morbidity and mortality ${ }^{4}$. In addition, infection is thought to play a major role in the genesis of pigment stones in SCD children. Studies have shown that 5-10\% of bile obtained from patients at cholecystectomy culture bacteria. $^{5}$

The prevalence of this disorder among the populations of SCD children vary widely, from $34 \%$ to $70 \%$ in the $\mathrm{USA}^{6-7}, 29 \%$ in Jamaica ${ }^{8}$ and from 4 to $25 \%$ in Africa ${ }^{9,10}$ Symptomatic biliary tract disease is difficult to diagnose in SCD because symptoms of gallstones mimic those of vaso-occlusive crisis involving the abdomen. ${ }^{11}$ In addition, the morbidity and mortality of emergency cholecystectomy in SCD is much higher than in elective cholecystectomy, hence the need for early detection ${ }^{12}$. Early detection allows for elective cholecytectomy which is associated with lower morbidity compared to emergency cholecytectomy.

The prevalence of this condition among children with sickle cell disease children in Benin City by means of ultrasonography is not known hence the need for this study. This study therefore aims to determine the prevalence of gallstones among steady state sickle cell disease children attending Outpatient clinic at the University of Benin Teaching Hospital, Benin-City, Nigeria.

\section{Methods}

This study was conducted at the University of Benin Teaching Hospital, Edo State Nigeria, a tertiary health facility in the South-South Nigeria. The study was a descriptive cross sectional study. It was conducted between April and September 2010. Sickle cell disease children attending the out- patient clinic and in steady state were recruited consecutively. Informed consent was obtained from the parents or care givers and the aim of the study was explained. Ethical committee approval was obtained. Exclusion criteria included presence of fever, pain crisis, and recent hospitalizations. Each patient was scanned just before breakfast. Scanning was done trans-abdominally using a Fukuda Sonic machine (Fukuda Denshi; Japan) with a $3.5 \mathrm{MHz}$ convex probe, with the subjects in supine position. Each measurement was taken three times and the average taken to minimize inter- observer's error. Gallstones was identified as discrete hyper-echoic foci with acoustic shadowing while sludge appeared as echoic material that layers or settles along the posterior gallbladder wall without shadowing . The antero-posterior, transverse and longitudinal diameters of the gallbladder were measured.
Statistical analysis was done using means and percentages. Students't-test was used to test for significance. At $95 \%$ confidence interval, $\mathrm{p}$ values less than or equal to 0.5 were considered significant.

\section{Results}

One hundred and one sickle cell disease (SCD) children aged 1-18years (mean age was $8.2 \pm 4.5$ yrs) were studied; 62 were males, while 39 were females. Ninety eight were haemoglobin $(\mathrm{Hb}) \mathrm{SS}$, while 3 were SC. Thirty five were aged 1-5 years, 44 were 6-10years and 22 were 11-18years (Table 1).

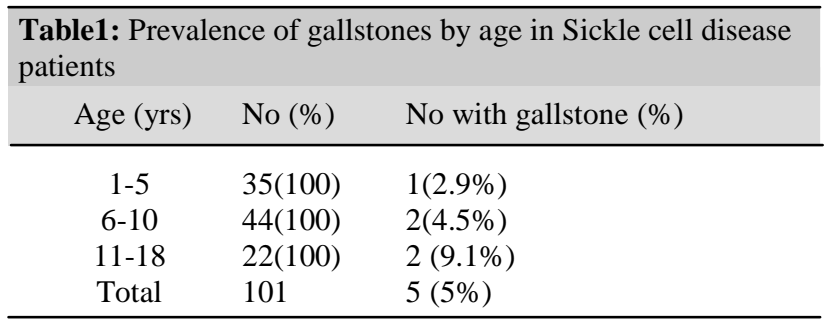

Gallstones were seen in five HbSS children, aged 5, 8, 10, and in two 18 year olds respectively. This consists of four males and one female with a male/ female ratio of $4: 1$. The overall prevalence of gall stones in this study is thus $5 \%$. The prevalence of gallstones increased with increase in the patients age (Table 1); $2.9 \%, 4.5 \%$ and $9.1 \%$ respectively in patients aged $1-5,6-10,11-18$ years respectively. All the patients with gallstone were HbSS. One child, a 14 year old female had biliary sludge. All except one were asymptomatic for the presence of the gallstone. He had right upper quadrant abdominal pain. This child was a five year old with seborrhoiec dermatitis in addition to the sickle cell disease.

The weight of the children studied ranged between 10$56 \mathrm{~kg}$ (mean $25.29 \pm 10.5 \mathrm{~kg}$ ). Their height ranged 77 $172 \mathrm{~cm}$ with a mean of $123.27 \pm 22.78$. The body mass index (BMI) ranged from10.6-22.5 with a mean of 15.71 \pm 1.87 , while the body surface area (BSA) ranged from 0.47-1.67 with a mean of 0.92 . The mean haemoglobin concentration $(\mathrm{Hb})$ was $7.4 \pm 1.1 \mathrm{~g} / \mathrm{dl}$, range was 5.4 $10.0 \mathrm{~g} / \mathrm{dl}$. The mean packed cell volume (PCV) was 22.7 $\pm 3.4 \%$ (range $16-32 \%$ ). There was a statistically significant difference in the mean weight of patients that had stones compared to patients that did not have stones; $\mathrm{p}=0.02$. However, there was no significant difference in the mean height, BMI, BSA, $\mathrm{Hb}$ and $\mathrm{PCV}$ values amongst the patents that had stones and those without have stones (Table 2).

Of the five patients with gallstone, one had undergone autosplenectomy, the spleen was present in the rest. 


\begin{tabular}{lllll}
\hline \multicolumn{5}{l}{ Table 2: Comparison of anthropometric and hematologic } \\
$\begin{array}{l}\text { parameters of patients with and without gallstones and sludge } \\
\text { Parameters } \\
\text { (mean) }\end{array}$ & $\begin{array}{c}\text { Patients with } \\
\text { gallstone/sludge }\end{array}$ & $\begin{array}{c}\text { Patients without } \\
\text { gallstone/sludge }\end{array}$ & $\begin{array}{c}\text { student } \\
\text { t-test }\end{array}$ & p-value \\
\hline & & & & \\
Weight $(\mathrm{kg})$ & 34.6 & 24.7 & 2.221 & 0.02 \\
Height $(\mathrm{cm})$ & 138.5 & 122.2 & 1.827 & 0.07 \\
$\mathrm{BMI}(\mathrm{kg} / \mathrm{m} 2$ & 16.4 & 15.6 & 1.021 & 0.31 \\
$\mathrm{BSA}(\mathrm{m} 2)$ & 1.1 & 0.9 & 1.638 & 0.1 \\
$\mathrm{Hb}(\mathrm{g} / \mathrm{dl})$ & 7.03 & 7.4 & 0.795 & 0.4 \\
$\mathrm{PCV}(\%)$ & 22.8 & 22.7 & 0.07 & 0.9 \\
\hline
\end{tabular}

\section{Discussion}

Chronic haemolysis associated with sickle cell disease facilitates the formation of gallstones and ultrasonography is a reliable, safe, reproducible, and non invasive method for investigating the biliary tract. It provides $88 \%$ sensitivity and $80 \%$ specificity for the diagnosis of gallstones $^{13}$. The incidence of gallstones in SCD children also appears to vary worldwide. In this study, the overall prevalence of gallstones was 5\%. This is similar to the $6 \%$ reported by Akinyanju and Ladapo in SCD children younger than 15 years in western Nigeria ${ }^{14}$, the $4.4 \%^{15}, 5 \%^{16}$, and $4.2 \%{ }^{17}$ respectively in reported by three other Nigerian studies and the $4 \%$ documented in Ghana. $^{18}$ The patients studied in the Ghana were aged 2-13 years and hence were younger than the 1-18 years old in this study. In the study conducted by Akinyanju, ${ }^{14}$ oral cholecystography was used and but this method is now abosolete. Studies by Adekile et $\mathrm{al}^{15}$ and Akamaguna et $\mathrm{al}^{16}$ used both cholecystography and ultrasonography while Nzeh et al ${ }^{17}$ used only ultrasonograghy. In Senegal, the prevalence of gallstones amongst SCD children aged 11 months to 22 years was $9.4 \% .{ }^{19}$ This is higher than reports from Ghana and Nigeria. This is probably because the age cohort in the Senegalese study was higher. In another study conducted in Sudan amongst 90 homozygous SCD children aged six months to 16 years, the prevalence of gallstones was $11.1 \% .^{20}$ This is higher than that which was documented in Ghana and this present study. Sudan is a north African country with probably different dietary habit as studies have estimated the prevalence of gallstones even amongst

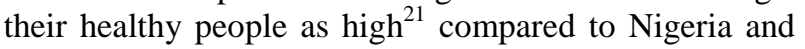
Ghana both of which are West African countries. Indeed the pattern of cholelithiasis in SCD children seems to mirror that of the general population where they reside. In Nigeria, the prevalence of gallstones is low in the general population $(0.8-1.8 \%)^{22}$ while that of the Sudanese people is $5.2 \%$. In Congo, a Central Africa country, in a study of 190 young SCD individuals aged $3-24 y r s, 58.4 \%$ were found to have gallstones ${ }^{23}$. The prevalence of gallstones in this study was lower than the $13 \%$ seen amongst the SCD children in Jamaican aged 5 years to 13 years $^{24}$. Again a difference in the dietary intake could be accountable for this, In Turkey, the prevalence of cholelithiasis amongst the 84 homozygous SCD aged 3-46 years that were studied was 50\%, of these 15/84 had had cholecystectomy for gallstones and $27 / 84$ had ultrasound evidence of gallstones ${ }^{25}$. In Italy, in a study of 527 SCD subjects, the prevalence of gall stone was $26 \%(57 / 217)$ amongst

subjects aged 5-19year ${ }^{26}$. Again, the prevalence of gallstones in the above studies was also much higher than that of this study although the Turkey study had much older patients. In the United Kingdom (UK), in a study of 131 patients with SCD aged 10-65 years, the prevalence of gallstones among the $95 \mathrm{SS}$ subjects was $58 \%{ }^{27}$. Again, the patients are older than the subjects in this study. In addition, UK is an European country where refined foods with high cholesterol and low fibre is consumed. Prevalence rates in the USA was $29 \%$ in SCD aged 2-18 years, 28 of the 31 subject studied had ultrasound scan. ${ }^{28}$ It is thought that the difference in dietary cholesterol and or fibre consumption account for the difference in the prevalence of gallstones in Africa and Europe and $\mathrm{USA}^{29}$.

The prevalence of gallstones is usually increased with increase age and by the age of 18 years $30 \%$ of SCD are expected to have developed gallstones ${ }^{30,31}$. In this study, the prevalence of gallstone amongst the children aged

11-18 years was $9.1 \%$.

The youngest child with of gallstones in this study was five years. This is similar to that in the Ghanaian study, however gallstones has been reported in a 2.5 year old SCD child ${ }^{20}$, and in an SCD toddler who was symptomatic $^{32}$.

Only one patient, a 5 year old, in this study was symptomatic, the complaint was that of pain in the right upper quadrant of the abdomen, this child additionally had seborrhoeic dermatitis. In Ghana, all the patients were asymptomatic $^{18}$, while in other studies, some of the subjects had already done cholecystectomy or were symptomatic $^{25-27}$.

One child who had undergone autosplenectomy had gallbladder stone, unlike other studies where those with autosplenectomy did not have gallstones ${ }^{18}$.

Biliary sludge is a complex mixture of mucous, calcium bilirubinate, and cholesterol in which hypersecretion of mucous leads to precipitation of bilirubin, forming a viscous material detectable by ultrasound ${ }^{33}$. Its natural history is variable; it may resolve spontaneously or may progress to gallstone formation ${ }^{34}$. Only one child was noted to have biliary sludge. Sludge is usually a precursor to the development of biliary stones as has been reported by some authors ${ }^{35}$. Hence, there is a need for this child to be followed up with routine scans for possible development of stone.

Previous studies have reported a male predominance in cases of gallstones in SCD children; the male: female ratio was $4: 1$ in this study, $12: 1$ in $\mathrm{Ghana}^{18}, 1.5: 1$ in Sudan $^{36}$, and 1.7:1 in Jamaica ${ }^{24}$.

Hemoglobin concentration was the only hematologic parameter that was done in this study because it is a routine investigation conducted at every clinic visit. In this study, the haemoglobin concentration was similar in patients with and without gallstones. This finding is similar to that reported by Attalla et $\mathrm{al}^{36}$, Bond et $\mathrm{al}^{27}$ and Sarnaik et $\mathrm{al}^{31}$. However, Webb et al reported a lower haemoglobin concentration in SCD patients with 
gallstones compared to patients without stones.

None of the patients in this study received cholecystectomy. However, in SCD, prophylactic cholecystectomy is advised even for asymptomatic gallstones as morbidity and mortality of emergency cholecystectomy in this setting is much higher than in elective cholecytectomy ${ }^{12}$.

\section{Conclusion}

In this study, prevalence of gallstones is low but consistent with other studies from Nigeria and Ghana. Gallstones were commoner in males than females and the prevalence increased with increase in age. Haematocrit and haemoglobin concerntration were similar amongst patients with and without gallstones.

\section{Author's Contributions}

Odunvbun ME: Conceptualization of the work, Data collection, Literature review, analysis, manuscript writing.

Adeyekun AA: Conceptualisation of the work,

Ultrasound scanning of patients

Conflict of interest: None

Funding: None

\section{Recommendation}

Gallstone can mimic abdominal crisis and other causes of surgical abdomen, therefore, there is need for routine screening with ultrasonography which is safe and inexpensive. In addition, screening allows for early detection and elective surgery for gallstones in asymptomatic patients which is safer than emergency surgery for symptomatic cases.

\section{References}

1. Odunvbun M.E, Okolo A.A, Rahimy C.M. Newborn Screening for Sickle Cell in a Nigerian Hospital. Public Health (2008) 122, 1111-6.

2. Cage Johnson, MD. Gall Bladder and Liver Disorders in Sickle Cell Disease: a Critical review, http:// sickle.bwh.harvard.edu/liver.html. Revised in January 2001. Accessed on 21/9/2011.

3. Schaad UB, Tschapeler H, Lentz MJ; Transient formation of precipations in the gall bladder associated with ceftriazone therapy. Pediatr Infect Dis 1986; 5: 70810.

4. Alexander-Reindorf C, Nwaneri RU, Worrel RG, Ogbonna A and Uzoma C. The significance of gallstones in children with sickle cell anemia. J Natl Med Assoc 1990; 82 (9):645-650

5. Maki T. Pathogenesis of calcium bilirubinate gallstone: The role of E. Coli, beta-glucuronidase and coagulation by inorganic ions, polyelectrolytes and agitation. Ann Surg. 1966; 164 (1):90-100

6. Barret-Connor E. Cholelithiasis in sickle cell anemia. Am J Med 1968; 45: 889-98.

7. CameronJL, Maddrey WC, Zuidema GD. Biliary tract disease in sickle cell anemia: surgical considerations. Ann Surg 1971; 174: 702-10.

8. McCall IW, Desai P, Sergeant BE, Sergeant GR. Cholelithiasis in Jamaican patients with homozygous sickle cell anemia. Am J Hematol 1977; 3:15-21.
9. Archampong EQ, Konotey-Ahulu FID, Biliary tract disease and sickle cell anemia in Korle Bu Teaching Hospital. Accra. Ghana Med J 1975; 14:175-180.

10. Adekile AD. The experience with cholelithiasis in patients with sickle cell anemia.in Nigeria. Am J Pediatr Haematol Oncol 1985;7 (3):261-4

11. Ariyan S, Shessel FS, Pickett LK. Cholecystitis, and cholelithiasis masking as abdominal crises in sickle cell disease. Pediatrics 1976; 58: 252-8.

12. Al-Salem AH. Should cholecystectomy be performed concomitantly with splenectomy in children with sickle cell disease? Pediatr Surg Int 2003;19:71-4.

13. Shea JA, Berlin JA, Escarce JJ, Clarke JR, Kinosian BP, Cabana MD, Tsai WW, Horangia N Malet PF, Schwartz JS et al. Revised estimates of diagnostic test sensitivity and specificity in suspected biliary tract disease. Arch Intern Med. 1994; 154 (22) 2573-81.

14. Akinyanyu O, Ladapo F: Cholelithiasis and biliary tract disease in sickle cell disease in Nigerians. Postgrad Med J 1979; 55: 400-2.

15. Adekile AD, Makanjuola D: Ultrasonography in children with sickle cell anemia. Niger J Paediatr 1983; 10: 35-8.

16. Akamaguna AI, Odita JC, Ugbodaga CI, Okafor LA: Cholelithiasis in sickle cell disease: a cholecystographic and ultrasonograpic evaluation in Nigerians. Eur J Radiol 1985;5:271-2.
17. Nzeh DA, Adedoyin MA. Sonographic pattern of gallbladder disease in children with sickle cell anemia. Pediatr Radiol. 1989;19 (5):290-2.

18. Darko R, Rodrigues OP, OliverCommey JO, Kotei CN. Gallstones in Ghanaian children with sickle cell disease. West Afr J. Med 2000; 24 (4) 295-8.

19. Diagne I, Badiane M, Moreira C, Signata-Sy H, Ndiaye O, LopezSall P, Preira-Sylla G, Camara B, Diouf S, Diack-Mbaye A, Fall M. Cholelithiasis in children with sickle cell anemia in DakarSenegal. Arch Dis Pediatr 1999; 6 1286-92.

20. Attalla BI. Sonographic Findings in Sudanese Children with Sickle cell anemia: J Diag Med Sonography 2010; 26(6) 276-80.

21. Abdel Bagi M, Arabi M, Abdel Rahim B, Al Asma A, Gibril M. Prevalence of gallstones in Sudan: First sonographic field study in adult population. Gastroenterol 1991:100:A307.

22. Da Rocha JT, AdesolaAO. Cholelithiasis in Nigerians. J Natl Med Assoc 1971; 1:47-50

23. Longo-Mbenza B, Ngiyulu R, Kizunda P, Kaluila M, Bikangi N. Gallbladder disease in young Congolese with sickle cell anemia: an ultrasound survey. J Trop Pediatr 2004;5:73-7.

24. Webb DKH, Darby JS, Dunn DT, Terry SI, Sergeant GR: Gallstone in Jamaican children with homozygous sickle cell diseases. Arch Dis Child 1989;64:693-6. 
25. Balci A, Karazincir S, Sanun O, Gali E, Daplan T, Cingiz C, Eglmez E:Prevalence of abdominal ultrasound abnormalities in patients with sickle cell disease: Diag Intern Radiol 2008; 14:1337.

26. Russo-Mancuso G, Romeo MA, Guardabasso V, Schiliro G; Survey of sickle cell disease in Italy. Haematologica 1998; 83 875-81

27. Bond LR, Hatty SR, Horn ME, Dick M, Meire HB, Bellingham AJ; Gallstones in sickle cell disease in the United Kingdom. $B r$. Med J. 1987; 295: 234-6

28. Lachman BS, Lazerson J, Starshark RJ, Vaughter FM, Werlin SL. The prevalence of cholelithiasis in sickle cell disease as diagnosed by ultrasound and cholecystography. Pediatrics 197964 (5) 601-3.
29. Cuevas A, Miquel JF, Reyes MS et al. Diet as a risk factor for cholesterol gallstones. J Am Coll Nutr 2004; 23:187-196

30. Walker TM, Hambleton IR, Sergeant GR. Gallstones in Sickle cell disease: Observation from the Jamaican cohort study. J Pediatric 2000;136: 80-5.

31. Sarnik S, Slovis TL, Corbett DP, Enami E, Whitten CF: Incidence of cholelithiasis in sickle cell anemia using ultrasonic gray-scale technique. J Pediatric 1980; 96: 1005-8.

32. Schinasi DA, Rakesh DM: Cholelithiasis in a toodler with sickle cell disease. Pediatr Emer Care 2011; 27 (6) 533-4.
33. Hussaini SH, Pereira SP, Veysey MJ, Kennedy C, Jenkins P, Murphy GM et al. Roles of gallbladder emptying and intestinal transit in the pathogenesis of octreotide induced gallbladder stones. Gut 1996; 36:775-83.

34. Podder U. Gallstones Disease in Children. Indian J Pediatr 2010; 4 (17) 945-53.

35. Al-Salem AH, Qaisrudin S. The significance of biliary sludge in children with sickle cell disease. Pediatr Surg Int 1998;13:14-6.

36. Attalla BAI, Karrar ZA, Ibouf G, Mohamed AO, Abdelwahab O, Nasir EM, El Seed MA. Outcome of cholelithiasis in Sudanese children with sickle cell anemia (SCA) after 13 years follow-up. Afr Hlth Scie 2013; 13(1): 154-9. 